\title{
Retraction Note: Coupled fixed point theorems without continuity and mixed monotone property
}

Ramesh Kumar Vats ${ }^{1}$, Vizender Sihag ${ }^{1}$ and Yeol Je Cho ${ }^{2^{*}}$

"Correspondence: yjcho@gnu.ac.kr

${ }^{2}$ Gyeongsang National University, Chinju, Korea

Full list of author information is available at the end of the article
One of the authors (Yeol Je Cho) found mistakes during the proofreading. He was advised to retract his paper [1] and resubmit the corrected version later for consideration.

\section{Author details \\ 'Department of Mathematics, National Institute of Technology, Hamirpur, 177005, India. ${ }^{2}$ Gyeongsang National} University, Chinju, Korea.

Received: 14 January 2014 Accepted: 14 January 2014 Published: 23 Jan 2014

\section{References}

1. Vats, RK, Sihag, V, Cho, YJ: J. Inequal. Appl. 2013, 217 (2013) (30 April 2013)

10.1186/1029-242X-2014-25

Cite this article as: Vats et al.: Retraction: Coupled fixed point theorems without continuity and mixed monotone property. Journal of Inequalities and Applications 2014, 2014:25

\section{Springer}

○2014 Vats et al: licensee Springer. This is an Open Access article distributed under the terms of the Creative Commons Attribution License (http://creativecommons.org/licenses/by/2.0), which permits unrestricted use, distribution, and reproduction in any medium, provided the original work is properly cited.
Submit your manuscript to a SpringerOpen ${ }^{\circ}$ journal and benefit from:

- Convenient online submission

Rigorous peer review

- Immediate publication on acceptance

Open access: articles freely available online

- High visibility within the field

Retaining the copyright to your article

Submit your next manuscript at $>$ springeropen.com 